\title{
CHARACTERISATION OF SOME ORNITHOBACTERIUM RHINOTRACHEALE STRAINS AND EXAMINATION OF THEIR TRANSMISSION VIA EGGS
}

\author{
J. VARGA*, L. FODOR and L. MAKRAI \\ Department of Microbiology and Infectious Diseases, Faculty of Veterinary Science, \\ Szent István University, H-1143 Budapest, Hungária krt. 23, Hungary
}

(Received October 31, 2000; accepted February 8, 2001)

\begin{abstract}
The biochemical characteristics and antibiotic susceptibility of 12 Ornithobacterium rhinotracheale strains isolated from chickens and turkeys suffering from respiratory clinical signs and the survival of some isolates on egg-shell and within chicken eggs during hatching were examined. All $O$. rhinotracheale strains showed typical biochemical characteristics. Among the 16 drugs examined, penicillin G, ampicillin (MICs ranging from $\leq 0.06 \mu \mathrm{g} / \mathrm{ml}$ to $1 \mu \mathrm{g} / \mathrm{ml}$ ), ceftazidim (with MICs from $\leq 0.06 \mu \mathrm{g} / \mathrm{ml}$ to $0.12 \mu \mathrm{g} / \mathrm{ml}$ ), erythromycin, tylosin, tilmicosin (with some exceptions MICs ranged from $\leq 0.06 \mu \mathrm{g} / \mathrm{ml}$ to $1 \mu \mathrm{g} / \mathrm{ml}$ ) and tiamulin (MICs varied from $\leq 0.06 \mu \mathrm{g} / \mathrm{ml}$ to $2 \mu \mathrm{g} / \mathrm{ml}$ ) were the most effective. Lincomycin, oxytetracycline and enrofloxacin also gave good inhibitions, but with most strains in a higher concentration (MICs ranged in most cases from $2 \mu \mathrm{g} / \mathrm{ml}$ to $8 \mu \mathrm{g} / \mathrm{ml}$ ). The other antibiotics inhibited the growth of $O$. rhinotracheale only in very high concentrations (colistin) or not at all (apramycin, spectinomycin, polymyxin B). At $37^{\circ} \mathrm{C}, O$. rhinotracheale did not survive on egg-shell for more than 24 hours, while upon inoculation into embryonated chicken eggs it killed embryos by the ninth day, and from the 14th day post-inoculation no $O$. rhinotracheale could be cultured from the eggs at all. These results suggest that $O$. rhinotracheale is not transmitted via eggs during hatching.
\end{abstract}

Key words: Ornithobacterium rhinotracheale, antibiotic susceptibility, egg transmission

Ornithobacterium rhinotracheale (Vandamme et al., 1994), originally regarded as a Pasteurella-like organism, can cause severe respiratory clinical signs in turkey (Hafez et al., 1993; Hinz et al., 1994; van Beek et al., 1994; Roepke et al., 1998; Sprenger et al., 1998) and chicken (Odor et al., 1997; Ryll et al., 1997), but several other bird species are also susceptible to it (Charlton et al., 1993; De Rosa et al., 1996; Hafez and Sting, 1999; van Empel and Hafez, 1999).

*Corresponding author; E-mail: varga@novell.vmri.hu; Fax: +36 (1) 251-9260 
The disease has been described in many countries (Charlton et al., 1993; Hafez et al., 1993; Léorat et al., 1994; van Beek et al., 1994; Hafez and Friedrich, 1998; Hafez and Sting, 1999; Sakai et al., 2000).

In Hungary the disease was first seen in four- to six-week-old broiler flocks in 1994 (Tanyi et al., 1995). The affected chickens showed weakness, ruffled feathers, occasionally head oedema, nasal discharge, quickly developing severe laboured breathing. Usually the whole flock was affected, and mortality varied from 3.5 to 14 per cent.

In this study the biochemical characteristics and antibiotic susceptibility of 12 O. rhinotracheale strains and the possibility of egg transmission of some selected isolates were examined.

\section{Materials and methods}

Twelve strains were examined, 10 of which originated from the trachea and lungs of three- to four-week-old chickens that had died of severe respiratory clinical signs in four different large-scale chicken flocks. Two strains were cultured from the lungs of succumbed turkeys in two flocks aged three weeks. The cases occurred in the autumn of 1995. The chicken flocks were located in the south-eastern part while the turkey flocks in the western part of Hungary. The samples were taken within $24 \mathrm{~h}$ after death. Blood agar with 10 per cent sheep blood was used for primary isolation by incubation at $37^{\circ} \mathrm{C}$ in air with 10 per cent carbon dioxide. Isolates were stored at $-78{ }^{\circ} \mathrm{C}$ until examined. Biochemical characteristics, compared to the reference strain LMG 9086, were examined as described by Vandamme et al. (1994).

The antibiotic susceptibility test was carried out by the dilution method in tubes using brain heart infusion broth (Difco) supplemented with two per cent chicken serum. The following antibiotics were tested: penicillin G (Sigma), ampicillin (Bristol), amoxicillin (Sigma), apramycin (Eli Lilly), ceftazidim (GlaxoWellcome), erythromycin (Sigma), tylosin (Eli Lilly), tilmicosin (Eli Lilly), tiamulin (Novartis), lincomycin (Upjohn), spectinomycin (Upjohn), oxytetracycline (Sigma), polymyxin B (Sigma), colistin (Sigma), enrofloxacin (Bayer) and trimethoprim (Egis). Twofold dilutions of each drug were prepared in saline and added to three $\mathrm{ml}$ broth in final concentrations ranging from 0.12 to $64 \mu \mathrm{g} / \mathrm{ml}$. Tubes were inoculated with $10 \mu \mathrm{l} O$. rhinotracheale suspensions containing $10^{5}$ $\mathrm{CFU} / \mathrm{ml}$. Minimal inhibition concentrations (MICs) were read following two days of incubation at $37^{\circ} \mathrm{C}$ in air.

Egg transmission of $O$. rhinotracheale was examined by the use of nineday-old SPF embryonated chicken eggs. One $\mathrm{ml}$ of a suspension of a mixture of four $O$. rhinotracheale strains (two of chicken and two of turkey origin), containing $9.2 \times 10^{9} \mathrm{CFU}$ bacteria/ml was sprayed on the surface of 30 eggs, respectively and $0.1 \mathrm{ml}$ of a dilution of the same suspension containing $9.2 \times$ 
$10^{7} \mathrm{CFU} / \mathrm{ml}$ was inoculated into the allantoic cavity of the embryos in 40 eggs. Eggs carrying $O$. rhinotracheale on the shell were kept at $4{ }^{\circ} \mathrm{C}$ in refrigerator, at room $\left(22\right.$ to $\left.25^{\circ} \mathrm{C}\right)$ temperature or in a bacteriological incubator at $37{ }^{\circ} \mathrm{C}$ for three weeks. Swab samples were taken every day from the surface (five times one square $\mathrm{cm}$ ) of all eggs and examined by culture for the presence of $O$. rhinotracheale. Eggs inoculated into the allantoic cavity were incubated under conventional conditions $\left(37.5^{\circ} \mathrm{C}, 65-70\right.$ per cent relative humidity, constant ventilation and automatic rotation of the eggs) for three weeks. Each day two eggs were opened and examined by culture for the presence of live bacteria within the eggs. Samples for culture were taken from three parts (allantoic cavity, yolk sack and the tissues of the embryo) of the eggs. Viability of the embryos was also recorded. Bacteria isolated from the surface of the eggs and the egg contents were identified using the same methods as in the case of the clinical isolates.

\section{Results}

All strains examined showed typical biochemical characteristics of $O$. rhinotracheale (Table 1).

Table 1

Biochemical characteristics of 12 Ornithobacterium rhinotracheale strains

\begin{tabular}{llll}
\hline Catalase & - & Pyrasinamidase & + \\
Oxidase & + & Arylsulphatase & - \\
OF test & fermentative & Lecithinase & - \\
Indole & - & Acid from & + \\
Urease (Lautrop's test) & + & Galactose & + \\
Methyl red & - & Glucose & + \\
Voges Proskauer & + & Lactose & + \\
Nitrate reduction & - & Starch & + \\
ONGP $(\beta$-galactosidase) & + & Maltose & - \\
Arginine dihydrolase & + & Mannose & - \\
Esculin hydrolysis & - & Mannitol & - \\
Phenylalanine deaminase & - & Sucrose & - \\
Gelatinase & - & Salicine & - \\
Hyaluronidase & + & Sorbitol & \\
Alkaline phosphatase & + & Xylose & \\
\end{tabular}

The strains were highly susceptible to penicillins (penicillin G, ampicillin), ceftazidim, the macrolide antibiotics (erythromycin, tylosin and tilmicosin) and to tiamulin (Table 2). With these antibiotics MICs ranged with very few exceptions from $\leq 0.06 \mu \mathrm{g} / \mathrm{ml}$ to $2 \mu \mathrm{g} / \mathrm{ml}$. Lincomycin, oxytetracycline and enrofloxacin were also active against $O$. rhinotracheale but the MICs of these drugs 
were in general much higher (in case of oxytetracycline they ranged between $2 \mu \mathrm{g} / \mathrm{ml}$ and $8 \mu \mathrm{g} / \mathrm{ml}$ ). Sensitivity of the strains against enrofloxacin ranged widely, there was one isolate with MICs $\leq 0.06 \mu \mathrm{g} / \mathrm{ml}$ and one isolate with MIC of $0.5 \mu \mathrm{g} / \mathrm{ml}$ while the MICs of all the other strains were much higher, ranging from $2 \mu \mathrm{g} / \mathrm{ml}$ to $8 \mu \mathrm{g} / \mathrm{ml}$. There were several antibiotics (apramycin, spectinomycin, polymyxin $\mathrm{B}$, colistin and trimethoprim) which did not inhibit the growth of $O$. rhinotracheale at all or only in very high concentrations.

Table 2

Minimal inhibitory concentrations (MIC) of different antibiotics against 12 Ornithobacterium rhinotracheale strains

\begin{tabular}{|c|c|c|c|c|c|c|c|c|c|c|c|}
\hline \multirow{2}{*}{ Antibiotics } & \multicolumn{11}{|c|}{ Number of strains with MIC $(\mu \mathrm{g} / \mathrm{ml})$ of } \\
\hline & $\leq 0.06$ & 0.12 & 0.25 & 0.5 & 1 & 2 & 4 & 8 & 16 & 32 & $\geq 64$ \\
\hline Penicillin G & 10 & 1 & & 1 & & & & & & & \\
\hline Ampicillin & 11 & & & & 1 & & & & & & \\
\hline Amoxicillin & 4 & 3 & & & 1 & & 1 & & & & 3 \\
\hline Apramycin & & & & & & & & & & & 12 \\
\hline Ceftazidim & 4 & 8 & & & & & & & & & \\
\hline Erythromycin & & 1 & 10 & 1 & & & & & & & \\
\hline Lincomycin & & & & & 8 & 2 & & & & 2 & \\
\hline Tylosin & 2 & 5 & 1 & 2 & & & 1 & 1 & & & \\
\hline Spectinomycin & & & & & & & & & & & 12 \\
\hline Tilmicosin & 5 & 5 & 1 & & 1 & & & & & & \\
\hline Tiamulin & 3 & 1 & 5 & 1 & & 2 & & & & & \\
\hline Oxytetracycline & & & & & & 2 & 9 & 1 & & & \\
\hline Polymyxin B & & & & & & & & & & & 12 \\
\hline Colistin & & & & & & & & & 2 & 2 & 8 \\
\hline Trimethoprim & & & & & & & & & & & 12 \\
\hline Enrofloxacin & 1 & & & 1 & & 3 & 5 & 2 & & & \\
\hline
\end{tabular}

Table 3

Survival of Ornithobacterium rhinotracheale on egg-shell and in chicken embryos

\begin{tabular}{|c|c|c|c|c|c|c|c|c|c|c|c|c|c|c|c|c|}
\hline \multirow{2}{*}{ Temperature } & \multicolumn{16}{|c|}{ Days post-infection } \\
\hline & 0 & 1 & 2 & 3 & 4 & 5 & 6 & 7 & 8 & 9 & 10 & 11 & 12 & 13 & 14 & 15 \\
\hline $37^{\circ} \mathrm{C}$ & $10 / 10^{*}$ & $0 / 10$ & $0 / 10$ & & & & & & & & & & & & & \\
\hline $22-25^{\circ} \mathrm{C}$ & $10 / 10$ & $7 / 10$ & $2 / 10$ & $0 / 10$ & & & & & & & & & & & & \\
\hline $4{ }^{\circ} \mathrm{C}$ & $10 / 10$ & $10 / 10$ & $10 / 10$ & $10 / 10$ & $10 / 10$ & $9 / 10$ & $7 / 10$ & $5 / 10$ & $5 / 10$ & $3 / 10$ & $2 / 10$ & $2 / 10$ & $0 / 10$ & & & \\
\hline $\begin{array}{l}37^{\circ} \mathrm{C} \text { in } \\
\text { hatchery } \\
(40 \text { eggs) }\end{array}$ & $2 / 2$ & $2 / 2$ & $2 / 2$ & $2 / 2$ & $2 / 2$ & $2 / 2$ & $2 / 2$ & $2 / 2$ & $2 / 2$ & $2 / 2^{* *}$ & $2 / 2$ & $2 / 2$ & $1 / 2$ & $1 / 2$ & $0 / 2$ & $0 / 10$ \\
\hline
\end{tabular}

*Number of eggs positive by culture/examined; ${ }^{* *}$ All embryos died 
The survival time of $O$. rhinotracheale on egg-shells depended to a high extent upon the conditions under which breeder eggs were stored (Table 3). At $37^{\circ} \mathrm{C}$ in a bacteriological incubator, O. rhinotracheale survived less than 24 hours, at room temperature less than three days, while on eggs kept in refrigerator they remained alive for 11 days.

$O$. rhinotracheale killed all the embryos by the ninth day after inoculation. From that day on no live embryos were detected. The bacteria remained alive in the egg contents until the 13th day post infection. From the 14th day on, no viable bacteria could be cultured from the eggs.

\section{Discussion}

The biochemical characteristics of $O$. rhinotracheale isolated from chicken and turkey flocks in Hungary were the same as the characteristics of the strains isolated by others (Hinz et al., 1994; Hafez, 1998).

Among the antibiotics, penicillins, the macrolide antibiotics (particularly erythromycin) and tiamulin were the most effective in vitro against $O$. rhinotracheale. In general, the susceptibility of our isolates was very similar to the susceptibility pattern of the strains examined by Devriese et al. (1995) in Belgium, but the distribution of the highly and less susceptible strains differed somewhat. For instance, most of our isolates were highly susceptible to tylosin (MICs of $90 \%$ of the strains were $0.5 \mu \mathrm{g} / \mathrm{ml}$ or less), while the susceptibility of most of the Belgian strains against this drug varied from $2 \mu \mathrm{g}$ to $4 \mu \mathrm{g} / \mathrm{ml}$.

The results of examination of the eggs suggest that $O$. rhinotracheale is not transmitted via breeder eggs, as under experimental conditions at $37{ }^{\circ} \mathrm{C}$ on the egg-shell these bacteria, especially when they dried up, died out within $24 \mathrm{~h}$, and as no live bacteria could be isolated from the breeder eggs 14 days postinoculation either.

\section{Acknowledgement}

This research was supported by a grant of the Hungarian Scientific Research Fund (OTKA), project no. T026055.

\section{References}

Charlton, B. R., Channing-Santiago, S. E., Bickford, A. A., Cardona, C. J., Chin, R. P., Cooper, G. L., Droual, R., Jeffrey, J. S., Meteyer, C. U., Shivaprasad, H. L. and Walker, R. L. (1993): Preliminary characterization of a pleomorphic gram-negative rod associated with avian respiratory disease. J. Vet. Diagn. Invest. 5, 47-51.

De Rosa, M., Dioual, R., Chin, R. P., Shivaprasad, H. L. and Walker, R. L. (1996): Ornithobacterium rhinotracheale infection in turkey breeders. Avian Dis. 40, 865-874. 
Devriese, L. A., Hommez, J., Vandamme, P., Kersters, K. and Haesenbrouck, K. (1995): In vitro antibiotic sensitivity of Ornithobacterium rhinotracheale strains from poultry and wild birds. Vet. Rec. 137, 435-436.

Hafez, H. M. (1998): Current status on the laboratory diagnosis of Ornithobacterium rhinotracheale 'ORT' in poultry. Berl. Münch. Tierärztl. Wschr. 111, 143-145.

Hafez, H. M. and Friedrich, S. (1998): Isolierung von Ornithobacterium rhinotracheale 'ORT' aus Mastputen in Österreich. Tierärztl. Umschau. 53, 500-504.

Hafez, H. M. and Sting, R. (1999): Investigations on different Ornithobacterium rhinotracheale 'ORT' isolates. Avian Dis. 43, 1-7.

Hafez, H. M., Kruse, W., Emele, J. and Sting, R. (1993): Eine Atemwegsinfektion bei Mastputen durch Pasteurella-ähnliche Erreger: Klinik, Diagnostik und Therapie. Poultry Conference on Poultry Diseases, Potsdam, Germany, pp. 105-112.

Hinz, K. H., Blome, C. and Ryll, M. (1994): Acute exudative pneumonia and airsacculitis associated with Ornithobacterium rhinotracheale in turkeys. Vet. Rec. 135, 233-234.

Léorat, J., Dudouyt, J., Doré, C. and Gardin, Y. (1994): Ornithobacterium rhinotracheale: une novelle raison du tousser. Filiéres Avicoles 559, 69-70.

Odor, E., Salem, M., Pope, C. R., Sample, B., Primm, M., Vance, K. and Murphy, M. (1997): Case report: isolation of Ornithobacterium rhinotracheale from commercial broiler flocks on the DelMarVa peninsula. Avian Dis. 41, 257-260.

Roepke, D. C., Back, A., Shaw, D. P., Nagaraja, K. V., Sprenger, S. J. and Halvorson, D. A. (1998): Isolation and identification of Ornithobacterium rhinotracheale from commercial turkey flocks in the Upper Midwest. Avian Dis. 42, 219-221.

Ryll, M., Hinz, K. H., Neumann, U., Löhren, U., Südbeck, M. and Steinhagen, D. (1997): Pilotstudie zur Prävalenz der Ornithobacterium rhinotracheale-Infektion bei Masthühnern in Nordwestdeutschland. Berl. Münch.Tieräztl. Wschr. 110, 267-271.

Sakai, E., Tokuyama, Y., Nonaka, F., Ohisi, S., Ishikawa, Y., Tanaka, M., Taneno, A. (2000): Ornithobacterium rhinotracheale infection in Japan: preliminary investigations. Vet. Rec. 146, 502-503

Sprenger, S. J., Back, A., Shaw, D. P., Nagaraja, K. V., Roepke, D. C. and Halvorson, D. A. (1998): Ornithobacterium rhinotracheale in turkeys: Experimental reproduction of the disease. Avian Dis. 42, 154-161.

Tanyi, J., Bistyák, A., Kaszanyitzky, É., Vetési, F. and Dobos-Kovács, M. (1995): Isolation of Ornithobacterium rhinotracheale from chickens, hens and turkeys showing respiratory symptoms (in Hungarian, with English abstract). Magyar Állatorvosok Lapja 50, 328-330.

van Beek, P. N., Van Empel, P. C. M., Van den Bosch, G., Storm, P. K., Bongers, J. H. and Du Preez, J. H. (1994): Ademhalingsproblemen, groeivertraging en gewrichtsontsteking bij kalkoenen en vleeskuikens door een Pasteurella-achtige bacterie: Ornithobacterium of 'Taxon 28'. Tijdschr. Diergeneesk. 119, 99-101.

Vandamme, P., Segers, P., Vancanneyt, M., Van Hove, K., Mutters, R., Hommez, J., Dewhirst, F., Paster, B., Kersters, K., Falsen, E., Devriese, L. A., Bisgaard, M., Hinz, K. H. and Mannheim, W. (1994): Ornithobacterium rhinotracheale gen. nov., sp. nov., isolated from the avian respiratory tract. Int. J. Syst. Bact. 44, 24-37.

van Empel, P. C. M. and Hafez, H. M. (1999): Ornithobacterium rhinotracheale: a review. Avian Pathol. 28, 217-227. 